\title{
The Macroeconomic Debate On Scaling up HIV/AIDS Financing
}

\author{
By Terry McKinley and Degol Hailu
}

\begin{abstract}
Introduction
The HIV/AIDS epidemic is a rapidly unfolding human development tragedy that demands an urgent, scaled-up global response. Yet ill-founded qualms about upsetting macroeconomic stability stand in the way of dramatically increasing Official Development Assistance (ODA) to tackle the epidemic.
\end{abstract}

Even the debate about a possible trade-off between halting HIV/AIDS and endangering macroeconomic stability is focused on the wrong target-namely, safeguarding economic growth (see IMF 2005 and Chowdhury and McKinley 2006). The overriding objective should be to swiftly reduce human misery. Debating the prospects for growth is of secondary importance.

A recent IMF publication (Gupta et al. 2006, p. 24) notes, helpfully, that not all aid is geared to promoting economic growth. Some forms of aid, such as for roads and electricity, have obvious direct links to growth. Other forms of aid, such as for education or health, might affect growth less directly and more over the

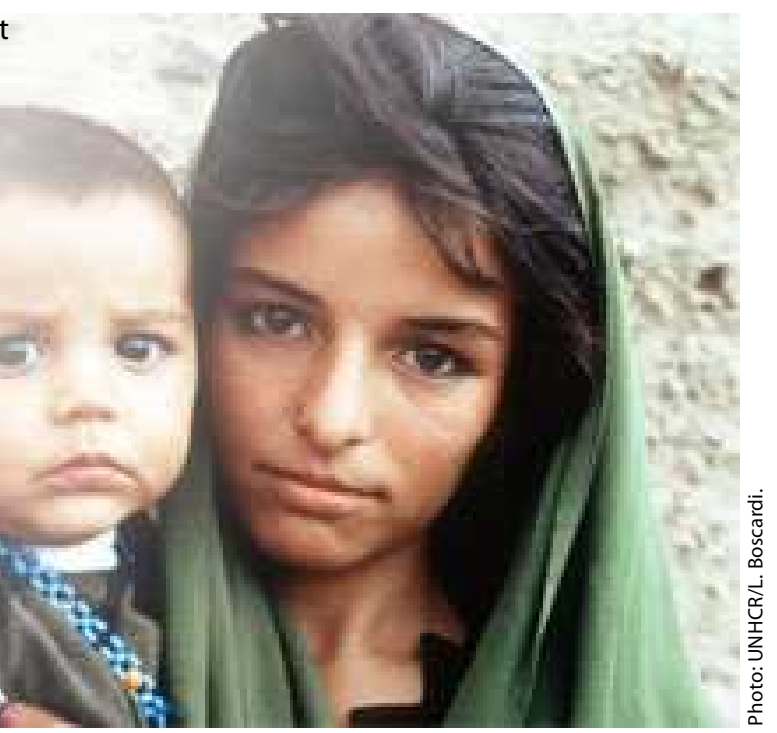
long term. But a third form of aid, such as for humanitarian relief, might have little connection to growth. This latter case applies to HIV/AIDS: combating it is justified primarily on the basis of arresting a human development crisis.

An earlier publication of the International Poverty Centre (McKinley 2005) dealt with the debate about the effect of scaling up ODA on growth. However, this policy research brief has a fundamentally different starting point. Its governing assumptions are that 1) economic growth is no more than a means to human development while 2) HIV/AIDS is a direct and disastrous assault on human development. Hence, it concludes that direct, human-development centred methods to confront the epidemic are urgently needed.

The relevant way to frame the debate on HIV/AIDS is to first ask whether such direct methods can successfully combat the epidemic. Then ask whether such methods are likely to exacerbate macroeconomic instability. If so, the next question is whether the macroeconomic price of success against the epidemic is too high. This policy research brief maintains that such a price is usually not high and where it threatens to be, coordination of economic policies could mitigate the danger. These policy lessons are the core concerns of this research brief.

\section{The Context for the Debate}

During the last 25 years, close to 25 million people have died from HIV/AIDS and over 40 million people are now HIV-positive. Since 1.5 million people a year currently contract the virus, the number of people who are HIV-positive is projected to rise to 60 million by the MDG target year of 2015. Thus, the epidemic is a huge threat to human well-being. It is also closely interwoven with underdevelopment: 95 per cent of all people who are HIV-positive live in developing countries.

MDG \#6 calls for halting and reversing the spread of HIV/AIDS by 2015. But a dramatic mobilization of resources would be needed to meet this goal. Between 1996 and 2005, spending on AIDS in developing countries did, indeed, increase-namely, 15-fold to US\$5 billion. But this still fell well short of the US\$12 billion needed at that time. By 2007 , the amount needed to halt the epidemic will rise to US\$ 20 billion.

In some countries in sub-Saharan Africa, there has already been a dramatic increase in external financing of HIV/AIDS programmes. Table 1 shows the percentage increase in such financing for the period 2002-2004 for selected countries. For Tanzania the percentage increase was almost 400 per cent while for Zambia it was almost 700 per cent. For countries such as Ethiopia, Uganda and Zambia, the scale of HIV/AIDS financing approximated or exceeded that for the whole health sector. 
Table 1

The Scaling up of External Financing for HIV/AIDS

in Selected African Countries, 2002-2004

\begin{tabular}{|lc|}
\hline Country & Percentage Change in Financing \\
\hline Ethiopia & 115 \\
Kenya & 82 \\
Malawi & 283 \\
Mozambique & 321 \\
Tanzania & 394 \\
Uganda & 221 \\
Zambia & 698 \\
\hline
\end{tabular}

Source: Lewis 2005.

\section{Does ODA Precipitate Macroeconomic Instability?}

Such a rapid and sizeable scaling up of ODA for HIV/AIDS has sounded alarm bells, however, among policy circles fixated on macroeconomic stability as the centrepiece of growth and development. In the countries cited in Table 1, external funding for HIV/AIDS ranged between five and 35 per cent of total ODA (Lewis 2005, p. 8). And much of the funding allocated each year does not get disbursed. So, funding for HIV/AIDS alone is unlikely, in most cases, to be a major cause of economy-wide instability. Nonetheless, where such funding is significant, national policymakers should carefully manage its macroeconomic impact.

A substantial ramping up of ODA should finance additional government spending on domestic goods and services for HIV/AIDS programmes. This will be made possible by converting the foreign exchange provided by ODA into domestic currency for government purchases. Supposedly, increased government purchases of domestic goods and services would invariably drive up their prices, causing a higher rate of inflation. This is supposed to apply, in particular, to 'non-tradable' goods and services, whose prices are not determined by international forces.

What will happen to the foreign currency (say U.S. dollars) originally provided by ODA, which are now held as net foreign assets by the Central Bank? The reserves could be sold domestically to the private sector for financing of imports. When dollars are exchanged for domestic currency, the latter is taken back out of the economy. If the stock of dollars is sold completely, the original injection of domestic currency would be fully offset. If inflation had increased when the government spent the domestic currency, it should subside when the domestic currency is extracted from domestic circulation. Moreover, the country should be able to use the ODA to deal better with a rise in inflation caused by more costly imports (such as oil).

The standard argument is that the increased demand for domestic currency (corresponding to the selling of U.S. dollars) should immediately increase the nominal exchange rate (i.e., the value of the domestic currency vis-à-vis the U.S. dollar). This effect will happen automatically if the exchange rate regime is fully flexible. If the exchange rate is fixed, it will happen by raising the domestic price index vis-à-vis the U.S. price index, i.e., raising the real exchange rate. This predicted appreciation of the exchange rate is usually labeled as a 'Dutch Disease' (because the discovery of natural gas in the Netherlands was an early example of how a large inflow of foreign exchange supposedly appreciated the exchange rate).

But what is the evidence for such an adverse impact of ODA on the exchange rate? Recent assessments find, in fact, that an upsurge in ODA has been associated with depreciation of the exchange rate. Gupta et al. (2006) and Foster and Killick (2006), taken together, studied the macroeconomic impact of scaling up ODA in seven African countries. In six of the seven, domestic inflation declined after such a scaling up. In four of the seven, the real exchange rate depreciated and in two others it changed little. So, there was very weak, if not contradictory, evidence of 'Dutch Disease' effects.

So far, there has been no adequate explanation for the depreciation of the exchange rate in these circumstances (see IMF 2005 and Gupta et al. 2006). One implicit explanation is that while the governments spent most of the domestic-currency equivalent of the ODA, the central bank did not sell the corresponding foreign-exchange reserves (in some cases because of IMF-mandated targets on reserves). Thus, there was limited upward pressure on the nominal exchange rate. A fuller explanation would involve, however, an examination of changes in the non-aid current account and the non-aid capital account.

A well-known IMF study, Prati et al. (2003), used a sophisticated regression model to test for the effect of ODA on the real exchange rate. Its main result was that a projected doubling of ODA would cause the real exchange rate to appreciate by only four per cent in the short run. Although statistically significant, this is a marginal effect. A general conclusion from the limited number of studies that have directly tested this relationship is that the evidence is inconclusive, at best.

\section{Are HIV/AIDS Expenditures Destabilizing?}

ODA financing of HIV/AIDS expenditures is not likely, by itself, to be destabilizing. In general, its effect will depend on both the composition and the size of expenditures. If aid for HIV/ AIDS is in-kind (such as medicines), this will, by definition, have no monetary impact. If the government uses foreign currency to purchase imports (instead of converting it into domestic currency), there will also be no effect.

If ODA-financed expenditures are focused on domestic 'nontradables', instead of exportables or importables, the monetary impact could, by contrast, be significant-in theory. However, in relatively small economies increasingly open to global trade 
and finance, the distinction between 'nontradables' and 'tradables' might not be easy to identify. Global forces have a much larger and broader impact on domestic inflation than ever before.

In order to understand the potential impact of ODA, we need to know what it will finance. UNAIDS estimates that for subSaharan Africa, 38 per cent of all expenditures will be for care and treatment, 35 per cent for prevention and 22 per cent for orphan support. Treatment involves substantial importing of antiretroviral medicines, which will have little monetary impact. Imports of related medical supplies and equipment (also 'tradables') should have similar negligible impacts.

What then could be the source of inflationary pressures? In low-income countries in sub-Saharan Africa, as well as elsewhere, wages and salaries are a large proportion of total healthcare costs. Health workers will be needed to dispense the medicines or run the medical equipment. In this case, would the increased demand for health personnel, especially skilled physicians and nurses, cause problems? On the whole, workers in such social sectors as healthcare are low-paid, especially after structural-adjustment budget cuts. A more likely problem is the shortage of doctors and nurses-precisely because their skills are 'tradable' globally. Many have left for higher salaries in more developed countries.

There are various ways to address these potential problems. One is to develop forms of treatment that are less reliant on highly trained personnel. For example, the model in Haiti has stressed the use of minimally trained outreach workers for lowincome communities. Another option is to devote more resources to upgrading the skills of health personnel. Concentrating investments on such capacity development should be a priority of any HIV/AIDS strategy. Also critical are investments in healthcare infrastructure and institutional capacity-especially important for the sustained treatment necessary for HIV/AIDS. Moreover, over the longer term, such investments will help mitigate any adverse monetary impacts of external financing of HIV/AIDS.

In sum, any adverse macroeconomic effects of spending on HIV/AIDS should not be significant enough to warrant major changes in the size of expenditures, or even in their composition-certainly not between broad priorities such as prevention or treatment.

\section{Managing Macroeconomic Policies}

Let us assume, contrary to recent evidence, that a substantial ODA- financed scaling up of expenditures on HIV/AIDS does, indeed, cause macroeconomic problems. How should macroeconomic policies be adjusted to address such a possibility? There should be little question that fiscal policies have to be expansionary. Because HIV/AIDS is a dire threat to human development, especially in sub-Saharan Africa, there is an urgent need for large-scale, broadly-targeted government programmes. ODA financing of larger government deficits is designed, in fact, precisely in order to dramatically expand domestic expenditures.

The composition of expenditures, such as on prevention or treatment, will depend, in part, on the HIV/AIDS prevalence rate in a country. Nevertheless, a significant proportion of financing should go to public investment that can expand the capacity of the health system. Otherwise, large quantities of imported medicines, such as antiretrovirals, cannot be delivered to the people who need them.

What often troubles many central bankers about expansionary fiscal policies is the spectre of accelerating inflation. But monetary policies should accommodate an expansion of government expenditures, not undermine it. This would entail abandoning the inordinate fear of inflation that induces central banks to set excessively low targets (e.g., 3-5 per cent per year) (see McKinley 2005). Fortunately, some IMF researchers have already concluded that inflation rates of 5-10 per cent are not likely to harm growth, at least in sub-Saharan Africa (Gupta et al. 2006, p. 18).

In many cases, moderate inflation should not deter policymakers from aggressively expanding expenditures in order to confront the HIV/AIDS threat. Halting the epidemic is a moral imperative. But it is also an economic priority since it will preserve higher productivity of the labour force-and will thus, conceivably, lower future inflation.

A major roadblock to implementing expansionary fiscal policies and accommodating monetary policies is the current penchant of central banks to use ODA to build up large stockpiles of foreign-exchange reserves. Table 2 shows, for example, that in Ethiopia, 71 per cent of net aid inflows went, in effect, into an increase in reserves, and in Tanzania, 100 per cent.

Table 2

The Impact of Aid (\% of GDP)

The difference in percentage before and during an aid surge

\begin{tabular}{|lcccc|}
\hline Country & $\begin{array}{c}\text { Net Aid } \\
\text { Inflows }\end{array}$ & $\begin{array}{c}\text { Non-aid Current } \\
\text { Account }\end{array}$ & $\begin{array}{c}\text { Non-aid Capital } \\
\text { Account }\end{array}$ & $\begin{array}{r}\text { Change in } \\
\text { Reserves }^{1}\end{array}$ \\
\hline Ethiopia & 8.0 & -1.6 & -0.7 & 5.7 \\
Ghana & 5.5 & 10.0 & -7.8 & 7.6 \\
Mauritania & 4.8 & -5.3 & 3.2 & 5.0 \\
Mozambique & 5.9 & -3.9 & -0.4 & 1.7 \\
Tanzania & 2.2 & 2.3 & -2.4 & 2.2 \\
Uganda & 4.7 & -1.3 & -2.8 & 0.7 \\
\hline
\end{tabular}

Note 1: Contrary to convention, a positive change in reserves is expressed as a positive percentage.

Source: Foster and Killick 2006, p. 14. 
To a certain degree, building up reserves is well advised. It will help central banks manage the exchange rate. This is important if aid-financed scaling up of government expenditures does, indeed, lead to higher inflation and appreciation of the exchange rate. With sufficient reserves, central banks could time their sale, i.e., their exchange for domestic currency, in order to moderate any pressures for appreciation.

This point highlights the need for coordinating monetary and exchange rate policies with fiscal policies (see Chowdhury and McKinley 2006). If the exchange rate were fully determined by market forces, it could fluctuate wildly, prompting the acceleration - if not the overshooting - of appreciation as a result of a large upsurge in ODA.

Table 2 also provides clues about why many of the countries studied by both the IMF and ODI did not experience appreciation of their exchange rate when net aid inflows surged. In five of the six countries listed, capital flowed out of the country in conjunction with an ODA inflow. In Tanzania, for instance, the non-aid capital that flowed out of the country (2.4 per cent of GDP) exceeded the net aid inflow (2.2 per cent). A similar negative correlation is evident in other countries such as Botswana, Kenya, Namibia and Senegal.

This suggests the need to manage the capital account. In most low-income countries, disincentives should be instituted against spiriting capital out of the country. One useful precaution would be to refrain from depositing foreign exchange in commercial banks, where it can be used easily to buy foreign assets. Without some regulation of capital outflows, national policymakers will have difficulty in implementing the fiscal and monetary policies needed to combat HIV/AIDS.

\section{Conclusion}

The current scale and composition of external financing for HIV/AIDS should not threaten macroeconomic stability. Even where instability might be exacerbated, carefully managed macroeconomic policies could abate any adverse consequences. However, such policies should not justify holding back government expenditures on HIV/AIDS programmes or dictate false trade-offs between various forms of expenditures, such as between prevention and treatment

\section{A full range of government expenditures should be urgently rolled out in order to confront the crisis. One qualification is that a significant share of ODA-financed expenditures should be channeled into investment to build up the capacity of national healthcare systems (viz., create more institutional capacity, more trained personnel and more health infrastructure). This will, in fact, help mitigate any ODA-induced inflationary pressures over the longer term.}

While fiscal policies should be expansionary, careful management of macroeconomic policies would also generally imply that 1) monetary policies be moderately relaxed in order to accommodate fiscal expansion, 2) exchange rate policies be designed to manage market-induced volatility, particularly from large capital inflows and 3) capital management techniques be instituted, especially in order to regulate capital outflows that can undermine the macroeconomic benefits of net aid inflows. Although stated as general rules, these policies would have to be adjusted, in fact, to the macroeconomic specifics of each country.

Terry McKinley and Degol Hailu

Senior Researcher and Acting Director, International Poverty Centre, Brasilia; and Policy Advisor, the UNDP Subregional Resource Facility, Port of Spain, Trinidad and Tobago.

\section{References:}

Chowdhury, Anis and Terry McKinley (2006). “Gearing Macroeconomic Policies to Manage Large Inflows of ODA: The Implications for HIV/AIDS Programmes," Working Paper \#17 of the International Poverty Centre, May, Brasilia.

Foster, Mick and Tony Killick (2006). “What Would Doubling Aid Do for Macroeconomic Management in Africa?” Working Paper \#264 of the Overseas Development Institute, April, London.

Gupta, Sanjeev, Robert Powell and Yongzheng Yang (2006). “Macroeconomic Challenges of Scaling Up Aid to Africa: a Checklist for Practitioners," Washington D.C.: IMF.

International Monetary Fund (2005). "The Macroeconomics of Managing Increased Aid Inflows: Experiences of Low-Income Countries and Policy Implications," August 8 draft, Policy Development and Review Department, Washington D.C.: IMF.

Lewis, Maureen (2005). “Addressing the Challenge of HIV/AIDS: Macroeconomic, Fiscal and Institutional Issues," Working Paper \#58, April, Center for Global Development, Washington D.C..

McKinley, Terry (2005). “Why Is the Dutch Disease Always a Disease? The Macroeconomic Consequences of Scaling Up ODA," Working Paper \#10 of the International Poverty Centre, November, Brasilia.

Prati, Alessandro, Ratna Sahay and Thierry Tressel (2003). "Is There a Case for Sterilizing Foreign Aid Inflows?" Paper presented at the Research Workshop "Macroeconomic Challenges in Low Income Countries," October 23-24, Washington D.C.: IMF.

International Poverty Centre

SBS - Ed. BNDES, $10^{\circ}$ andar

70076-900 Brasilia DF

Brazil

povertycentre@undp-povertycentre.org

www.undp.org/povertycentre

Telephone +556121055000

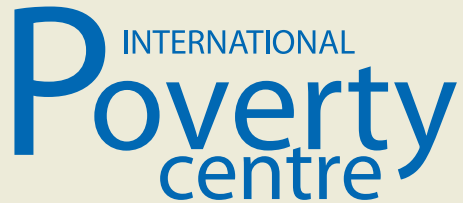

United Nations Development Programme 